\title{
The Purchase of Books in Europe
}

W

E CAN MAKE a start from the point at which the total aspect of European acquisitions was a confused and disorganized one, and work forward from there. We can dispose of the British Isles easily. Imports from Britain never ceased entirely nor, on the other hand, are they even now quite satisfactory. Transmission is still slow, editions are quickly exhausted, older items are quickly sold, and prices are high. But this picture is too well known to require further discussion.

Spain and Portugal. Dealings with Spain and Portugal also were never entirely suspended during the war, and now may be said to be approaching normal. The Bibliografia Hispanica comes regularly, as do catalogs from several Spanish and Portuguese bookshops. Auction catalogs have arrived months after the auctions have taken place. Recently we have attempted to get these in time to make bids. An upswing in Spanish publishing is perceivable. There is also an attempt to establish exchange relations on the part of Spanish and Portuguese institutions. The Department of State has sent to the peninsula, as publications officer, Mrs. Marie Cannon, who was the reporter on the book trade for the Handbook of Latin American Studies. She will report currently on book trade conditions, and it is hoped that her reports can be made generally available. Among the most active dealers from whom we hear are Vergara, Aguado, Beltran, José Porter, Livraria Portugal, and Livraria Tavares Martins.

1 Revised version of a paper presented at the Conference of Eastern College Librarians, Columbia University, Nov. 24, 1945 .
France. Commercial relations with France have been open since Oct. 5, 1945, when the Treasury issued its general license No. 92. There are still many, impediments, however, to freedom of commercial intercourse, including certification by the French government of those of its nationals who are entitled to credits in this country, other controls placed upon credit transactions, the scarcity of shipping, and the actual lack of books. But the Bibliographie de la France has been published continuously during the war, as has also "Biblio." Meanwhile, though some of the old journals are dead, new ones are arising. France appears eager to return to her place in the publishing world. While shortage of paper is likely to last for at least another year, satisfactory arrangements can be made by American librarians through the booksellers who have a knowledge of both countries. Also, there has been installed in the Bibliothèque $\mathrm{Na}$ tionale, through the enterprise of an American firm, microfilm equipment which will make it possible to place orders in this country for microfilms from France.

Belgium and Holland. The situation in Belgium and Holland is similar to that in France. Commerce is open, but the means are generally lacking, books are few, and governmental restrictions are many. $\mathrm{Mr}$. Nijhoff has described his inability to send materials stored on prewar orders for the simple lack of packing cases. He hopes to use Smithsonian Institution boxes recently sent to the Royal Library for the purpose. Brinkman's Catalogus has been received, but the Bibliographie de Belgique and the 
Revue Bibliographie Belge have not been arriving. Booksellers' catalogs from both countries, including catalogs of Flemish materials, among them Het Boek in Vlaanderen, have come.

Switzerland. From the point of view of European acquisitions, Switzerland has enjoyed an enviable position during the war. At no time has she been cut off entirely from the rest of the Continent, and only briefly from the rest of the world. Consequently, there have come into Switzerland-and even out of it-all during the war Continental publications which otherwise it would have been impossible to see. The holdings of the League of Nations Library (accessions lists available), of the International Labour Office, and of the National Library at Berne will require first consideration when the wartime bibliography of Continental serials is reviewed, particularly for any program of republication or microfilming. Commercial dealings with Switzerland are possible under various restrictions, and the Swiss are reported to be making strenuous efforts to fill the place left vacant by the crumbling of the German book industry. L.C. receives the Bibliographisches Bulletin der Schweiz, Das Schweizer Buch, and several dealers' catalogs.

Scandinavia. There is little to report for Denmark, Norway, and Sweden. Commercial shipments are still difficult because of effective restrictions of wartime credit and shipping control. It is expected, however, that the former will soon be eased. No copies of the Dansk Boghandlertidende or of the Danish Aarskatalog since 1943 have been received, with the exception of isolated smuggled issues, but we have been informed that copies are being held. The same situation is true for the Norskbokhandlertidende and the Norwegian Aarskatalog. The Svensk Bokhandels-tidning and shipments of mail have come from
Sweden. Booksellers in all countries appear to be active, and contacts have been renewed and orders placed. However, genuinely productive arrangements probably can be made only through noncommercial channels.

Italy. For Italy, the picture in regard to acquisitions is confused. The booktrade is-apparently and comparatively speaking at least-flourishing, and prices are about double those before the war. Nardecchia, Olschki, Lange, Liberma, Fucile, and others are active. Il Libro Italiano ceased in 1943 and has probably not been replaced. Catalogs are procurable. The Library of Congress has about 6500 Italian monograph titles, 1940-45. Shipping and credit transactions are under stifling restrictions but it is expected that these may be relaxed before long, at least from this country, although no doubt they will continue to remain under local controls. A symptom of easing is the relaxation of the State Department in favor of Mr. Hafner's present trip to Italy.

Hungary. Two Hungarian booksellers (Grille and Tisza Testvéreck) have been heard from, but no commercial dealings have been possible. Some material is stored.

Balkans. For the other Balkan countries there is nothing to report. Austria is lost in the picture with Germany. L.C. is receiving military gazettes of the American Occupation Forces through the courtesy of General Hume, lately of the Army Medical Library, but they have so far revealed nothing about the booktrade.

Russia. Commercial dealings with Russia remained open during the war. Materials were difficult to obtain, due to slowness in shipping, restrictions on export, and the effect of American laws regarding registration of foreign agents. There is probably not a single up-to-date set of Knizhnaia Letopis available in the country. There 
are, however, signs of improvement here. Four Continent Book Corporation of New York (importers for Mezhdurodaia Kniga) will now sell books across state lines in this country (see the Library Journal for Jan. I, 1946), and our State Department is taking active steps to promote interchange of library materials between the two countries.

Czechoslovakia. What reports we have of Czechoslovakia indicate the absence of both book stocks and a booktrade. The same situation is true of Poland.

Germany. There are no export dealings with Germany, but the booktrade is reorganizing. All publishing ventures in the American Zone require licensing by the Information Control Division of the Military Government. Toward the end of December 1945 a total of twenty-three newspapers had been licensed in the Zone, beginning with the Frankfurter Rundschau on July 31, 1945, in addition to the Americanoperated newspaper Die Neue Zeitung; a total of seventy-six book and magazine publishers had been licensed; and fifty-two books and pamphlets had been published. (See the Weekly Information Bulletin published by the Reports and Information Branch, Office of Military Government, U.S. Zone, U.S.F.E.T., No. 22, Dec. 22, r 945 , p. 6,8 .) We are attempting to collect multiple copies of these books. A report from our representative, Reuben Peiss (of Harvard and the Interdepartmental Committee for the Acquisition of Foreign Publications) on Oct. I3, I945, revealed that "a number of influential publishers, some of them formerly from Leipzig, are setting up a temporary branch of the 'Boersenverein' in the American Zone"probably at Weisbaden, "and will compile a bibliography of all new publications. Eventually they hope to turn the depository copies over to the Deutsche Bücherei. The editors of the new Boersenblatt informed me that they would be happy to lay aside fifty copies if we would undertake to give them sufficient information concerning publishing in America and furnish them with American materials." We are arranging to send fifty copies of the Publishers' Weekly and of the New York Times Book Review in response to this suggestion.

Some time ago we asked Maj. Douglas Waples, chief of the Publication Section of the Information Control Division of American Group Control, for information regarding publishers' stocks and plates. His reply, which has not since been amplified, was to the effect that the information was still to be gathered; that stocks are largely destroyed, as are also plates; but that there remain, in many cases, Belegexemplare which might be used in a republication program, for example, by microfilm or photooffset.

\section{Zones Other Than American}

For zones other than the American there is less information. Conflicting reports come from the Russian Zone. The most reliable is to the effect that the Russians are reconstituting the Leipzig booktrade but removing the control to Dresden, where a new control board is said to have been set up. Just before I left Washington, I asked Lt. David Clift (late of Columbia, now of Yale, but actually on his way to join Reuben Peiss in Frankfurt) to scan the official gazettes which we get from the French Zone. He found nothing in any way relating to publications. There is, however, reported to be even greater activity there than in the American Zone. Meanwhile, too, there has been an interzonal conference in Frankfurt on the disposition of documents, so that possibilities for exchange of materials between zones are shaping up.

We are conducting such purchases in Germany as are possible, through Broer- 
mann in Berlin, checking against a set of D.N.B. But the real acquisition problem in Germany, so we are informed, is not one of purchase but of finding out what is in the vast stocks which have come into the hands of the Army from military and party libraries.

One general comment may be made with respect to the whole of the Continent. Everywhere there is a tremendous desire to ascertain what has been going on in the United States during the war and to procure American publications. This desire is matched, for the most part, only by the inability of those countries to purchase from us to the extent they need. Everywhere, consequently, there is found a desire to enter into exchange relationships which will avoid the restrictive effect of credit and import controls. From Italy and Holland have come suggestions for exchange of publications with which to suffice the needs of many libraries; from France and Russia, suggestions of plans embracing a representation of the whole book production of the countries involved ; from Denmark, Czechoslovakia, and Belgium suggestions for less extensive but still substantial arrangements. No one institution is in a position to meet any of these suggestions all the way; but there is an opportunity in the present situation, if we could only properly explore it, which should not be lost.

So much for a hurried glance at general conditions. Certain special problems or arrangements may now be briefly discussed.

During the past few years the government has itself, through the Office of Strategic Services, the Interdepartmental Committee for the Acquisition of Foreign Publications, the Department of State, and the Library of Congress, been the principal promoter of the acquisition of European (as well as other) book materials, and has made, through the Alien Property Custodian's republication program, many important foreign publications available in photo-facsimile to libraries generally.

With the liberation of various Continental countries, however, libraries generally began to inquire about facilities which might be afforded them for securing from these countries the book materials which had, possibly, been stored for them during the war, as well as currently published materials. It was obvious that, in the absence of commercial channels, governmental channels would have to be employed. Specifically, at the June meeting of the Association of Research Libraries, the question was raised whether libraries generally might not share the use of the channels enjoyed by the Library of Congress.

At that time L.C.'s channels consisted of the following: We had a representative (Manuel Sanchez) attached first to the Allied Control Commission in Italy, then later to the American embassies both in Rome and Paris. He could make use of both Army and State Department resources for payment and shipment and could command, as well, certain other forms of assistance such as jeeps, trucks, packing boxes, stenographers, etc. In both countries he made excellent arrangements with local booksellers. This program of direct representation by the Library of Congress was at that time, however, rapidly giving way to representation by the State Department, on behalf of L.C., through publications officers at various principal foreign service posts who were to perform for us (and for the other governmental agencies) the operations with respect to publications which could not be undertaken through regular commercial channels.

\section{Department of State}

Consequently, before we could respond to the request of the A.R.L. we had to con- 
sult the Department of State. Mr. MacLeish was at that time Assistant Secretary of State for Public and Cultural Relations, so our request was addressed to an understanding and sympathetic ear. As a result, on Aug. 4, 1945, Mr. MacLeish wrote to Dr. Evans stating that

The Department of State agrees with the Library of Congress' view that the national interest is directly affected by the holdings of the many private research libraries. It would, therefore, interpose no objection in principle to the employment of federal government facilities to assist in maintaining their specialized collections where normal channels of acquisition are inoperative. It is believed, however, that certain basic understandings should be made clear at the outset. The department would wish to be assured that the private libraries had agreed upon and carefully planned a program of cooperative buying and that they would continue to support such a plan as long as federal assistance were granted them.

This response was communicated to the Association of Research Libraries, which was eager to adopt the arrangement of which the possibility was presented. The mechanics of the arrangement, however, remained to be worked out, including not only the mechanism of the operations of procurement and distribution themselves, but also the determination of what would constitute eligibility for participation and the preparation of a schedule of priorities for the distribution of materials which might be available in limited numbers of copies.

\section{Library of Congress}

Meanwhile, the Library of Congress, assured of the eventual success of the plan, began to act. In order not to lose the fleeting moment, pending discussions in the course of which the existing book stocks would rapidly disappear by sale, by rising prices, or (particularly in the case of Germany) to the pulping mill, we immediately sent Mr. Sanchez back over his tracks, with instructions to purchase three additional copies of what he had already purchased for us. We appointed a new representative for France and the Lowlands, and one for Germany who should also cover Switzerland, Austria, Czechoslovakia, and such other countries as he might be able to reach. The instructions to these agents have been to purchase three copies of everything of any research value and, in the case of books having a high reference value, to use their own judgment as to needs, even going as high as fifty copies (that is the source of Mr. Peiss' authorization for his action, on which I just reported, in the case of the Boersenblatt). (These instructions have since been modified in the case of those countries where commercial channels are now open, so as to restrict purchasing to imprints earlier than 1946.)

Meanwhile, the Army was getting many requests from various libraries for permission to send representatives to Germany or to get books out of Germany. The President, by executive order, had established the publication board with specific responsibility for making available for the use of American business and industry the information derivable from German industrial, scientific, and technological sources. There were conflicting demands, with, however, a similar objective.

\section{Satisfactory Formula}

A formula providing a satisfactory solution to the situation, at least from the librarians' point of view, resulted from a meeting in Dr. Evans' office on Sept. 19, 1945. This meeting was originally called to consider the acquisitions program through the Department of State but, coinciding with Carl M. White's return from Germany, it was able to consider the German situation also. Representatives of the principal library as- 
sociations and of the principal research libraries there agreed to a plan of distribution, through the Library of Congress, of any captured materials which the $W$ ar Department might release following the completing of its own uses. It was agreed, also, that such captured materials would be lumped for distribution with the materials being purchased by agents of the Library of Congress and that the same plan of distribution should govern all materials. It was agreed that a schedule to allocate priorities, as among libraries in competition for the same kind of materials, should be established by a Committee to Advise on the Distribution of Foreign Acquisitions, to be made up of representatives of the American Library Association, the Association of Research Libraries, the Joint Committee on Importations (itself representative of a large number of libraries and library associations), the American Council of Learned Societies, the National Research Council, the Social Science Research Council, and the American Council on Education. As soon as these organizations named their representatives (consisting of Robert B. Downs, Keyes D. Metcalf, Thomas P. Fleming, Donald Goodchild, George W. Corner, Elbridge Sibley, and President David Robertson, of Goucher), L.C. issued a release dated Oct. 15, 1945, explaining the program and soliciting, on behalf of the committee, expressions of desire for participation, to be accompanied by statements of the fields of interest and the amount of money which could be devoted to the purpose. It was sent to ninety libraries, and also appeared in the Library Journal for Dec. I, I945, and the A.L.A. Bulletin for January 1946.

The tabulation of these preliminary results showed that a more particularized statement of the libraries' needs would be required. Consequently, some 325 libraries were again polled by the committee in a cir- cular issued by Mr. Downs on Dec. Io, 1945, accompanied by a classification scheme of 253 headings devised by Edwin E. Williams, of Harvard. To this circular approximately one hundred libraries responded and, at this writing, the advisory committee is wrestling with the unenviable job of assigning priorities for distribution in each case in which more than one library has entered a request to cover a particular subject. These cases, of course, are numerous; many libraries, for example, want material in chemistry, in music, and in nuclear physics. On the other hand, however, the geographic distribution of requests has been, with necessary limitations, good, and there are no "orphan" subjects. Priorities are therefore to be assigned, first on the basis of the size of existing collections, and second, with a view to obtaining wide geographic distribution. It is expected that a satisfactory, at least a working, arrangement will soon be obtained. This will be reported for confirmation to the libraries concerned, and thereafter L.C. will request the participating libraries to deposit funds which will make it possible to pay for the operations which have already been undertaken on this score and for ensuing operations, such as sorting, classifying, and packing.

To guide our purchasing agents abroad and to facilitate as well our own operations in sorting, searching, and checking material as it comes in, we have been preparing checklists of the European imprints of the war years which are now available in Washington. The checklist of Italian material has been run off. It covers the period 194045 , records some annuals but few other serials, and contains about 6500 entries. Although now available only in a small number of copies (which are being reserved for the use of the libraries engaging in the cooperative acquisitions project), it will shortly be made generally available through 
a reprint to be made on behalf of the library by G. E. Stechert \& Co. The German list is similarly being reproduced for the library by Edwards Brothers, Inc., and it, too, will be generally available. A French list will follow.

\section{Prewar Orders}

Several other subjects may be of interest: first, as to publications stored in liberated and enemy countries on prewar orders. $\mathrm{Mr}$. Metcalf has for some time been discussing with Major James Horan, the coordinator of War Department Libraries, methods for getting this material out of Europe. At the September I9 meeting of which I have spoken, L.C. offered Major Horan the services of its representative, Reuben Peiss, in trying to loosen up these materials. We sent him such information as to the stored materials as could be gathered in this country; Peiss has reported to Lt. General Bedell Smith, has gathered considerable other information, and started some shipments on the way from the American Zone. He tells me, by phone, that he continues daily to collect information regarding location of stores. He cannot, however, do a thorough job on this matter until we get him additional assistance, which we are, this very minute perhaps, doing. Peiss has not as yet, however, uncovered the materials in the Russian Zone held by Harrassowitz and others, but news regarding these materials is daily expected.

I recur to the special problem of Russian acquisitions. The Department of State has agreed (in a letter from Mr. MacLeish to Mr. David on Aug. 8, 1945) to lend its facilities to the acquisition of Russian materials if arrangements are worked out between the interested libraries and the $\mathrm{Li}$ brary of Congress on the basis of a division of responsibility in the various fields. After long waiting, the Library of Congress will soon have representation in Moscow through a publications officer in the embassy, and we are stockpiling for his use current American publications to be used in exchange, so that we are all ready to start. Meanwhile, responses to the proposal are still coming in from libraries. The Library of Congress feels its position in this matter to be one of some responsibility, for several reasons. We are, as you know, just concluding a survey, supported by the Rockefeller Foundation, of existing Russian collections, and we are engaging in a drive, also supported by the foundation, to get our own collections of Russian materials cataloged. This will leave us with perhaps fifteen thousand duplicates, and we propose to distribute these duplicates only in the interest of a cooperative program and of accepted responsibility for coverage in particular fields.

\section{Republication}

Finally, republication. We won't know until all the materials are in what is still missing, of what there are too few copies, etc. Meanwhile, certain steps can be taken. Edwards Brothers are republishing the Halbjahrverzeichniss for 1941 and 1942 and D.N.B. for 1943 and 1944 , making use of our copies at least in part for this purpose, so that it will be possible for librarians to know-to the extent that this publication furnishes the record-what has been published in Germany. Meanwhile, L.C. has acquired, in thirty tremendous rolls, the checking record of German periodicals kept by the Deutsche Bücherei since 1937, and we have even discovered, we believe, an exemployee of the Bücherei who can help to interpret the record. I notice that many of the entries are marked "Geh," so that we can hope that it includes a record of much secret material. This is, of course, an invaluable record, and there is some prospect that it may be abstracted and published. 
Similarly, we have also a copy of the Bücherei's record of depository copies. This may serve to supplement or check the accuracy of D.N.B.

We need, however, someone to give attention, more than sporadically, to matters affecting republication; and our representatives in Europe are much too busy keeping the rain out of the warehouses and getting books into boxes to be able to think of anything else. We need someone who can visit each of the countries of Europe, thinking less of the immediate and more of the ultimate aims of librarianship: the relations between libraries, exchange and other; methods; the place of libraries in European culture, and in particular, German culture; whether and how America through its libraries can and should exert a beneficial force in the reconstitution of Europe. Mr. Metcalf, Dr. Lydenberg, and I were speaking of these things the other day in Dr.
Evans' office, and I remarked to Dr. Lydenberg, "Don't be surprised if you find the European Theatre asking for you." I am happy to be able to report today that the Theatre has asked for Dr. Lydenberg to become a member of the Library of Congress mission in Germany. That assignment is, for the present, of course, just an umbrella, out from which Dr. Lydenberg can readily step. The important thing is, I think, that the director of the A.L.A.'s International Relations Office is in a position from which he can take a considered view of things in Europe, from the point of view of an American librarian. Thus I am able to conclude these overlengthy remarks on acquisitions by reporting that acquisition is a two-way traffic, and that what we have begun with the motive of mere procurement may well provide the means for securing much more useful and enduring results in the future. 